(c) American Dairy Science Association, 2006.

\title{
Treatment of Cycling and Noncycling Lactating Dairy Cows with Progesterone During Ovsynch ${ }^{1}$
}

\author{
J. S. Stevenson, ${ }^{\star 2}$ J. R. Pursley,† H. A. Garverick,‡ P. M. Fricke,§ D. J. Kesler,\# \\ J. S. Ottobre,\| and M. C. Wiltbank§ \\ *Department of Animal Sciences and Industry, Kansas State University, Manhattan 66506-0201 \\ †Department of Animal Science, Michigan State University, East Lansing 48824 \\ ¥Department of Animal Science, University of Missouri, Columbia 65211 \\ §Department of Dairy Science, University of Wisconsin-Madison, Madison 53706 \\ \#Department of Animal Sciences, University of Illinois, Urbana 61801 \\ ||Department of Animal Sciences, The Ohio State University, Columbus 43210
}

\section{ABSTRACT}

Our objective was to determine whether progesterone (P4) supplementation during an Ovsynch protocol would enhance fertility in lactating dairy cows. Lactating dairy cows $(n=634)$ at 6 locations were assigned randomly within lactation number and stage of lactation to receive the Ovsynch protocol [OVS; synchronization of ovulation by injecting GnRH $7 \mathrm{~d}$ before and 48 $\mathrm{h}$ after $\mathrm{PGF}_{2 \alpha}$, followed by one fixed-time AI (TAI) 16 to $20 \mathrm{~h}$ after the second GnRH injection] or Ovsynch plus a controlled internal drug release (CIDR) P4-releasing insert for $7 \mathrm{~d}$, beginning at the first $\mathrm{GnRH}$ injection (OVS + CIDR). Blood was sampled to quantify P4 $10 \mathrm{~d}$ before the first GnRH injection, immediately before the first GnRH injection, at the time of CIDR removal, before the $\mathrm{PGF}_{2 \alpha}$ injection (1 to $2 \mathrm{~h}$ after CIDR insert removal), and $48 \mathrm{~h}$ after the $\mathrm{PGF}_{2 \alpha}$ injection to determine cyclicity status before initiation of treatment, luteal status at the $\mathrm{PGF}_{2 \alpha}$ injection, and incidence of luteal regression. Overall, conception rates at 28 (40 vs. $50 \%)$ and $56 \mathrm{~d}(33 \mathrm{vs} .38 \%)$ after TAI differed between OVS and OVS + CIDR, respectively; but a treatment $\times$ location interaction was detected. Compared with OVS, pregnancy outcomes were more positive for OVS + CIDR cows at 4 of 6 locations $28 \mathrm{~d}$ after TAI and at 3 of 6 locations $56 \mathrm{~d}$ after TAI. An interaction of luteal status (high vs. low) before CIDR insert removal and $\mathrm{PGF}_{2 \alpha}$ injection with pretreatment cycling status indicated that cows having low $\mathrm{P} 4$ at $\mathrm{PGF}_{2 \alpha}$ injection benefited most from P4 supplementation (OVS + CIDR = $36 \%$ vs. OVS $=18 \%$ ), regardless of pretreatment cycling

Received November 11, 2005

Accepted February 3, 2006.

${ }^{1}$ This project was funded partly by the NC-113 Regional Research Project of the USDA Cooperative State Research, Extension, and Education Service. Contribution no. 06-59-J from the Kansas Agricultural Experiment Station, Manhattan.

${ }^{2}$ Corresponding author: jss@k-state.edu status. Pregnancy loss between 28 and $56 \mathrm{~d}$ after TAI was greater for noncycling cows (31\%) compared with cycling cows (16\%). Pregnancy loss for cows receiving P4 (21\%) did not differ from that for cows not receiving P4 (21\%). Supplementation of P4, pretreatment cycling status, and luteal status before $\mathrm{PGF}_{2 \alpha}$ injection altered follicular diameters at the time of the second $\mathrm{GnRH}$ injection, but were unrelated to pregnancy outcomes. Incidence of multiple ovulation was greater in noncycling than in cycling cows. Further, cows having multiple ovulations had improved pregnancy outcomes at 28 and $56 \mathrm{~d}$ after TAI. In summary, a CIDR insert during the Ovsynch protocol increased fertility in lactating cows having low serum $\mathrm{P} 4$ before $\mathrm{PGF}_{2 \alpha}$ injection. Improved pregnancy outcomes were observed at some, but not all locations.

Key words: controlled internal drug release, Ovsynch, dairy cow, fertility

\section{INTRODUCTION}

Poor conception rate in lactating dairy cows ranks as one of the most limiting factors to dairy profitability. Conception rates decreased from $66 \%$ in 1951, to $50 \%$ during 1973 to 1985 (Butler and Smith, 1989), to about $45 \%$ for cows inseminated at spontaneous estrus and $35 \%$ for cows receiving a timed AI (TAI) in 2000 (Lucy, 2001). This decrease in fertility was concurrent with a dramatic increase in DMI and milk production per cow.

A negative relationship exists between DMI and circulating concentrations of progesterone (P4) in lactating dairy cows (Sangsritavong et al., 2002); and lactating dairy cows have serum concentrations of P4 less than those in nonlactating nulliparous heifers (Wiltbank et al., 2000; Wolfenson et al., 2004). Progesterone is important to fertility as demonstrated by a positive correlation between serum $\mathrm{P} 4$ before $\mathrm{AI}$ and subsequent conception rate (Fonseca et al., 1983; Folman et al., 1990). 
Several studies have examined the effect of exogenous progestin supplementation on fertility in lactating dairy cows. Conception rate was greater for cows that received a P4-releasing intravaginal device during $7 \mathrm{~d}$ before the second of 2 injections of $\mathrm{PGF}_{2 \alpha}$ ( $14 \mathrm{~d}$ between injections), compared with controls (Folman et al., 1990). Decreased conception rates, however, were reported in lactating dairy cows and heifers without a corpus luteum $(\mathbf{C L})$ at the end of treatments with $\mathrm{P} 4$ or norgestomet, compared with females having a CL at the end of progestin treatment (Smith and Stevenson, 1995).

Combining progestin treatments with protocols similar to Ovsynch (synchronization of ovulation by injecting GnRH $7 \mathrm{~d}$ before and $48 \mathrm{~h}$ after $\mathrm{PGF}_{2 \alpha}$ followed by one fixed-time AI $16 \mathrm{~h}$ after the second GnRH injection) administered to noncycling suckled beef cows improved conception rates resulting from inseminations after estrus or those resulting from TAI (Lamb et al., 2001; Stevenson et al., 2003). Similar studies in lactating dairy cows reported improved conception rates in first-lactation cows treated with intravaginally placed P4-releasing controlled internal drug release (CIDR) inserts during an Ovsynch protocol (experiment 1; ElZarkouny et al., 2004; Moreira et al., 2004a) and in all cows treated with CIDR inserts during an Ovsynch protocol in which estrous cycles were presynchronized (Presynch; Moreira et al., 2004b). In contrast, no positive effects of the $\mathrm{P} 4$ via the CIDR insert were detected in another study in which cows were treated with Presynch + Ovsynch (experiment 2; El-Zarkouny et al., 2004).

The current experiment was designed to test the hypothesis that providing P4 (via a CIDR insert) during Ovsynch before TAI would improve fertility, particularly in noncycling cows and those having no CL at the time of $\mathrm{PGF}_{2 \alpha}$ injection. Specifically, our objective was to determine whether $\mathrm{P} 4$ administration before induced luteal regression might improve overall fertility by either increasing conception rates or reducing pregnancy losses in lactating dairy cows determined retrospectively to be cycling or noncycling before the onset of treatment.

\section{MATERIALS AND METHODS}

\section{Experimental Locations}

This study was a collaborative project of the North Central Regional Research Project 113 of the Cooperative States Research, Education, and Extension Service (CSREES). Similar treatments were applied to lactating Holstein cows in 6 locations (Illinois, Kansas, Michigan, Missouri, Ohio, and Wisconsin) in which coauthors were located. A total of 634 cows were enrolled between
December 1998 and June 1999. A similar experimental design was used at each location. Cows were organized into breeding clusters in which they were inseminated on the same day in each particular breeding cluster. Details, variations in data collection, and methodologies for each location are listed below.

Illinois. Lactating cows enrolled at this location were part of the University of Illinois research herd composed of 200 Holstein cows, with an annual rolling herd average of 9,500 kg of milk. Cows were housed in stanchions and were milked twice daily. The experiment was conducted in 96 cows organized in 5 breeding clusters in which cows were inseminated between February and May 1998. Although DIM in all cows ranged from 60 to 396 at TAI, 58 of the 96 cows were inseminated before 100 DIM.

Ultrasonography was conducted by using a transrectal 5.0-MHz linear-array transducer (Aloka 500V; Corometrics Medical Systems, Inc., Wallingford, CT). Serum $\mathrm{P}_{4}$ concentrations were quantified by enzyme immunoassay (Kesler et al., 1990), with intra- and interassay coefficients of variation of 5 to $10 \%$.

Kansas. Lactating cows were enrolled on a commercial dairy farm in northeastern Kansas. The herd consisted of 500 Holstein cows, with an annual rolling herd average of $11,500 \mathrm{~kg}$ of milk. Cows were milked thrice daily and fed a TMR consisting of chopped alfalfa, corn silage, whole cottonseed, and a concentrate-mineral mix (offered twice daily) to meet or exceed NRC (1989) recommendations for lactating cows. Cows had access to fresh water ad libitum at 3 locations in each 100 cow pen, which consisted of feed-line self-locking head gates and free stalls bedded with sand. All procedures, including hormone injections, blood collection, TAI, and ovarian ultrasonography, were conducted while cows were locked up at the feed line after the morning milking. The experiment was conducted in 184 cows organized in 8 breeding clusters in which cows were inseminated between January and June 1999. All cows were inseminated at first service between 50 and 77 DIM. Some of these results were reported earlier (El-Zarkouny et al., 2004).

Ultrasonography was conducted by using a transrectal 5.0-MHz linear-array transducer (Aloka 500V; Corometrics Medical Systems, Inc.). Serum $\mathrm{P}_{4}$ concentrations were quantified by radioimmunoassay (Skaggs et al., 1986) with intra- and interassay coefficients of variation of 6.9 and $6.4 \%$, respectively.

Michigan. Lactating cows were enrolled at a commercial dairy farm composed of 750 Holstein cows, with an annual rolling herd average of $12,720 \mathrm{~kg}$ of milk. Cows were housed in freestall barns, fed a TMR balanced for milk production, and milked thrice daily. The experiment was conducted in 94 cows organized in 4 
breeding clusters in which cows were inseminated between May and June 1998. Although DIM in all cows ranged from 74 to 264 at TAI, 69 of the 94 cows were inseminated before 100 DIM.

Ultrasonography was conducted by using a transrectal 7.5-MHz linear-array transducer (Aloka 900; Corometrics Medical Systems, Inc.). Serum P4 concentrations were quantified by radioimmunoassay (Progesterone Coat-a-Count kit, Diagnostic Products Cooperation, Los Angeles, CA) with intra- and interassay coefficients of variation of 5.6 and $9.1 \%$, respectively.

Missouri. Lactating cows were enrolled at the University of Missouri experimental herd composed of 225 Holstein cows, with an annual rolling herd average of $9,500 \mathrm{~kg}$ of milk. The experiment was conducted in 99 cows organized in 10 breeding clusters in which cows were inseminated between December 1998 and May 1999. Although DIM ranged from 67 to 154 in all cows, 78 of the 99 cows were inseminated before 100 DIM. Cows were fed a TMR consisting of alfalfa hay, alfalfa silage, corn silage, whole cottonseed, soybean hulls, soybean meal, ground corn, and a premix containing minerals and vitamins. Diets were based on NRC (1989) recommendations. Cows were housed in a freestall barn with feed provided twice daily in an alley adjacent to the freestall area. For blood sample collections, hormone injections, TAI, and ultrasonographic examination of ovaries, cows were moved from the freestall area to a laboratory barn with holding facilities for the procedures.

Ultrasonography was conducted by using a transrectal 7.5-MHz linear-array transducer (Aloka 200; Corometrics Medical Systems, Inc.). Serum $\mathrm{P}_{4}$ concentrations were quantified by radioimmunoassay (Progesterone Coat-a-Count kit, Diagnostic Products Cooperation; Kirby et al., 1997) with intra- and interassay coefficients of variation of 4.2 and $8.2 \%$, respectively.

Ohio. Holstein cows were enrolled at 2 commercial dairy farms consisting of approximately 300 cows each. Cows were milked twice daily and fed a TMR consisting of chopped alfalfa, corn silage, whole cottonseed, and a concentrate-mineral mix (offered twice daily) to meet or exceed NRC (1989) recommendations for lactating cows. All procedures, including hormonal injections, blood collection, TAI, and ovarian ultrasonography, were conducted while cows were locked up at the feed line or when cows were moved through a working alley and cattle chute. The experiment was conducted in 93 cows organized in 6 breeding clusters in which cows were inseminated between May and July 1998. Although DIM ranged from 50 to 292 in all cows, 52 of the 93 cows were inseminated before 100 DIM.

Ultrasonography was conducted by using a transrectal 5.0-MHz linear-array transducer (Aloka 500V; Coro- metrics Medical Systems, Inc.). Serum P4 concentrations were quantified by radioimmunoassay (Clapper et al., 1990) with intra- and interassay coefficients of variation of 7.7 and $10.7 \%$, respectively.

Wisconsin. Holstein cows were enrolled at a commercial dairy farm in southern Wisconsin. The herd consisted of 1,100 lactating Holstein cows, having an annual rolling herd average of $11,000 \mathrm{~kg}$ of milk. Cows were milked thrice daily and fed a TMR consisting of chopped alfalfa, corn silage, whole cottonseed, and a concentrate-mineral mix (offered twice daily) formulated to meet or exceed NRC (1989) recommendations for lactating cows. Cows had access to fresh water ad libitum at 3 locations in each pen, which consisted of feed-line self-locking head gates and free stalls bedded with sand. All procedures, including hormonal injections, blood collection, TAI, and ovarian ultrasonography, were conducted while cows were locked up at the feed line. All 68 cows were inseminated in a single breeding cluster. Although DIM ranged from 57 to 223 in all cows, 59 of the 68 cows were inseminated before 100 DIM.

Ultrasonography was conducted by using a transrectal 7.5-MHz linear-array transducer (Aloka 500V; Corometrics Medical Systems, Inc.). Serum P4 concentrations were quantified by enzyme-linked immunoabsorbent assay (Rasmussen et al., 1996) with intra- and interassay coefficients of variation of 4.3 and $15.5 \%$, respectively.

\section{Treatments}

Within location, cows were blocked by lactation number, stratified by DIM, and assigned randomly to receive either of 2 treatments. Controls received the Ovsynch protocol $(n=321)$ consisting of $100-\mu \mathrm{g}$ i.m. injections of GnRH (Cystorelin; Merial, Ltd., Duluth, GA) $7 \mathrm{~d}$ before and $48 \mathrm{~h}$ after a $25-\mathrm{mg}$ i.m. injection of $\mathrm{PGF}_{2 \alpha}$ (Lutalyse; Pharmacia Animal Health, Kalamazoo, MI). Treated cows $(n=313)$ received the Ovsynch protocol (OVS) and received at the time of the first GnRH injection a controlled internal drug release (OVS + CIDR) insert containing $1.9 \mathrm{~g}$ of P4 (CIDR-B; InterAg, Hamilton, New Zealand), which was removed 1 to $2 \mathrm{~h}$ before the $\mathrm{PGF}_{2 \alpha}$ injection. The first injection of $\mathrm{GnRH}$ was administered at random stages of the estrous cycle.

Cows in both treatments received one TAI, 16 to 20 $\mathrm{h}$ after the second GnRH injection. At each location, herd personnel who were generally unaware of treatments to which cows were assigned performed inseminations. Semen used for AI was chosen by herd managers at each location as part of routine management of their herd. Therefore, semen and inseminators were confounded with location. 


\section{Blood Collection}

Blood samples were collected from all cows by venipuncture of the median caudal vein or artery $10 \mathrm{~d}$ before the first GnRH injection, immediately before the first $\mathrm{GnRH}$ injection and CIDR insertion, at the time of removal of the CIDR insert [at only 2 (Missouri and Wisconsin) of the 6 locations were all controls and treated cows sampled at this time], immediately before $\mathrm{PGF}_{2 \alpha}$ injection (1 to $2 \mathrm{~h}$ after CIDR insert removal), and 48 $\mathrm{h}$ after the $\mathrm{PGF}_{2 \alpha}$ injection. Blood sera samples were stored at $-20^{\circ} \mathrm{C}$ until concentrations of $\mathrm{P} 4$ were measured as described previously for each location.

Our rationale for waiting 1 to $2 \mathrm{~h}$ after CIDR insert removal before collecting blood before the $\mathrm{PGF}_{2 \alpha}$ injection was based on $\mathrm{P} 4$ clearance rates reported for ovariectomized cows (Rathbone et al., 2002). In that study, after a 7-d insertion period, a waiting period of 1 to 2 $\mathrm{h}$ was sufficient for concentrations of $\mathrm{P} 4$ in 4 ovariectomized cows to decrease from $2.8 \mathrm{ng} / \mathrm{mL}$ (upon insert removal) to $0.75 \mathrm{ng} / \mathrm{mL}$ by $1 \mathrm{~h}$ and $0.5 \mathrm{ng} / \mathrm{mL}$ by $2 \mathrm{~h}$ after insert removal.

\section{Transrectal Ultrasonography}

Ovarian structures (antral follicles $\geq 5 \mathrm{~mm}$ and CL) were monitored by using transrectal ultrasonography as described previously (Lamb et al., 2001). Ovulatory response to the second $\mathrm{GnRH}$ injection was determined by the presence of a single, or multiple, large antral follicle(s) at the time of the second GnRH injection, and absence of the follicle(s) $48 \mathrm{~h}$ later.

Pregnancy status was assessed by using ultrasonography in all cows $28 \mathrm{~d}$ after TAI and was reassessed 56 $\mathrm{d}$ after TAI for cows diagnosed pregnant at $28 \mathrm{~d}$. A positive pregnancy diagnosis was confirmed by presence of uterine fluid and a large CL or by visualization of a viable (heart beat) of the embryo or fetus. Conception rate was defined as the percentage of inseminated cows that were pregnant at 28 and $56 \mathrm{~d}$ after TAI. Pregnancy loss between 28 and $56 \mathrm{~d}$ after TAI was calculated as the proportion of cows that were not pregnant $56 \mathrm{~d}$ after TAI, expressed as a percentage of cows pregnant at $28 \mathrm{~d}$ after TAI.

\section{Definitions of Various Reproductive Statuses}

Occurrence of estrous cycles (cycling vs. noncycling) before the onset of treatments was determined by serum concentrations of $\mathrm{P} 4$ assessed in samples collected $10 \mathrm{~d}$ before and immediately before the first GnRH injection. When both samples of blood serum contained concentrations of $\mathrm{P} 4<1 \mathrm{ng} / \mathrm{mL}$ (low P4; Low-Low), the cow was classified as noncycling. When either or both of the paired samples contained concentrations of $\mathrm{P} 4$ $\geq 1 \mathrm{ng} / \mathrm{mL}$ (high P4; High-High, Low-High, or HighLow), the cow was classified as cycling.

Induced ovulation was defined as the proportion of cows that were not cycling at the onset of treatments, but in which high $\mathrm{P} 4$ was detected $7 \mathrm{~d}$ after the first GnRH injection. Consequently, noncycling cows having low P4 $7 \mathrm{~d}$ after the first $\mathrm{GnRH}$ injection (at time of the $\mathrm{PGF}_{2 \alpha}$ injection) were defined as having no induced CL, whereas those with high P4 were assumed to have an active induced CL. Cycling cows having high P4 7 $\mathrm{d}$ after the first $\mathrm{GnRH}$ injection (at time of the $\mathrm{PGF}_{2 \alpha}$ injection) were defined as having an active CL, whereas those having low P4 were assumed to have had early luteolysis (Lamb et al., 2001).

Regression of the CL was defined as the proportion of cows with high $\mathrm{P} 4$ in serum at the time of the $\mathrm{PGF}_{2 \alpha}$ injection, but in which concentrations of $\mathrm{P} 4$ decreased to $<1 \mathrm{ng} / \mathrm{mL}$ after $48 \mathrm{~h}$ (i.e., low P4).

Ovulation was defined as the proportion of cows that ovulated 1 or more follicles (multiple ovulation) by 48 $h$ after the second GnRH injection.

\section{Statistical Analyses}

Models used to analyze conception rates at 28 and $56 \mathrm{~d}$, pregnancy loss from 28 to $56 \mathrm{~d}$, incidence of single and multiple ovulation after the second GnRH injection, induced ovulation, incidence of high concentrations of $\mathrm{P} 4$ before $\mathrm{PGF}_{2 \alpha}$, incidence of low $\mathrm{P} 4$ by $48 \mathrm{~h}$ after $\mathrm{PGF}_{2 \alpha}$, follicle diameters, incidence of ovulation (including multiple ovulation), concentrations of $\mathrm{P} 4$ in serum just before CIDR insert removal (2 locations only) and 1 to $2 \mathrm{~h}$ later just before $\mathrm{PGF}_{2 \alpha}$ injection (all locations), and CL regression consisted of the following independent variables: treatment $(n=2)$, location $(n=6)$, lactation number ( 1 vs. $2+)$, pretreatment cycling status (0 vs. 1), daily milk yield and DIM at TAI as covariates, and 2-way interactions of pretreatment cycling status, location, and lactation number with treatment. Follicle diameters at the time of the second $\mathrm{GnRH}$ injection were categorized into 2 size classes $(\leq 15$ or $>15 \mathrm{~mm})$ to examine relationships with milk yield $(<34,35$ to 43 , and $>43 \mathrm{~kg}$ ). Analyses of follicle diameters were conducted using ANOVA (procedure GLM), whereas all binominal variables were analyzed by using procedure GENMOD (SAS Institute, Inc., Cary, NC).

Pretreatment cycling status (0 vs. 1 ), concentrations of $\mathrm{P} 4$ ( $\geq 1$ vs. $<1 \mathrm{ng} / \mathrm{mL}$ ) or luteal status before $\mathrm{PGF}_{2 \alpha}$, and their interaction were added to the other independent variables cited previously. Analysis of pretreatment cycling status was conducted by using procedure GENMOD consisting of a model having location, lactation number, location $\times$ lactation number, plus daily milk yields and DIM at TAI as covariates. Differences 
Table 1. Characteristics of lactating dairy cows in response to the Ovsynch protocol or the combination of a controlled internal drugreleasing (CIDR) insert plus Ovsynch

\begin{tabular}{|c|c|c|c|c|c|c|c|c|c|c|c|}
\hline Location & $\begin{array}{l}\text { Daily } \\
\text { milking } \\
\text { frequency }\end{array}$ & $\begin{array}{l}\text { Total } \\
\text { cows, } \mathrm{n}\end{array}$ & $\begin{array}{l}\text { Days in } \\
\text { milk, }{ }^{1} \mathrm{~d}\end{array}$ & $\begin{array}{l}\text { Milk } \\
\text { yield, }{ }^{1} \\
\text { kg/d }\end{array}$ & $\begin{array}{l}\text { Cycling } \\
\text { status, }^{2}\end{array}$ & $\begin{array}{l}\text { Induced } \\
\text { ovulation, }{ }^{3}\end{array}$ & $\begin{array}{l}\text { High } \\
\mathrm{P} 4 \text { at } \\
\mathrm{PGF}_{2 \alpha}{ }^{4}\end{array}$ & $\begin{array}{l}\text { Low P4 } 48 \\
\text { h after } \\
\text { PGF }_{2 \alpha}{ }^{5}\end{array}$ & $\begin{array}{l}\text { CL } \\
\text { regressed }^{6}\end{array}$ & $\begin{array}{l}\text { Ovulated } \\
\text { after } \\
\mathrm{GnRH}^{7}\end{array}$ & $\begin{array}{l}\text { Multiple } \\
\text { ovulation }^{7}\end{array}$ \\
\hline $\mathrm{KS}$ & $3 \times$ & 184 & $60 \pm 6$ & $46 \pm 11$ & 41 & 52 & 63 & 95 & 94 & 88 & 14.7 \\
\hline MI & $3 x$ & 94 & $107 \pm 45$ & $39 \pm 11$ & 89 & 70 & 80 & 90 & 89 & 85 & 10.6 \\
\hline MO & $2 \times$ & 99 & $88 \pm 17$ & $39 \pm 9$ & 91 & 56 & 80 & 95 & 94 & 92 & 5.1 \\
\hline Average & & & $89 \pm 42$ & $39 \pm 11$ & 71 & 57 & 73 & 93 & 92 & 89 & 10.3 \\
\hline
\end{tabular}

${ }^{1}$ Average DIM or milk yield ( $\left.\pm \mathrm{SD}\right)$ at the time of AI.

${ }^{2}$ Proportion of cows that had at least one sample having elevated ( $\geq 1 \mathrm{ng} / \mathrm{mL}$ ) concentration of progesterone (P4) 0 to $10 \mathrm{~d}$ before initiating the Ovsynch (OVS) protocol (injections of GnRH $7 \mathrm{~d}$ before and $48 \mathrm{~h}$ after $\mathrm{PGF}_{2 \alpha}$, plus timed AI $16 \mathrm{~h}$ after the second GnRH injection). Percentage of cows at each location determined to be cycling and subsequently treated with OVS or OVS + CIDR were: IL (94, 94); KS (39, 43); MI (89, 90); MO (90, 91); $\mathrm{OH}(69,57)$; and WI $(61,89)$, respectively.

${ }^{3}$ Proportions of noncycling cows (low P4 in 2 blood samples collected 0 and $10 \mathrm{~d}$ before the first GnRH injection) with high P4 at $7 \mathrm{~d}$ after the first GnRH injection of Ovsynch.

${ }^{4}$ Proportion of cows having high ( $\geq 1 \mathrm{ng} / \mathrm{mL}$ ) concentrations of $\mathrm{P} 4$ in serum at $\mathrm{PGF}_{2 \alpha}$ injection. Blood samples were collected 1 to $2 \mathrm{~h}$ after CIDR insert removal just before the injection of $\mathrm{PGF}_{2 \alpha}$.

${ }^{5}$ Proportion of cows having low $(<1 \mathrm{ng} / \mathrm{mL}) \mathrm{P} 4$ at $48 \mathrm{~h}$ after $\mathrm{PGF}_{2 \alpha}$.

${ }^{6}$ Proportion of cows with high $\mathrm{P} 4$ in serum at the time of the $\mathrm{PGF}_{2 \alpha}$ injection of Ovsynch in which concentrations of $\mathrm{P} 4$ decreased to $<1$ $\mathrm{ng} / \mathrm{mL}$ after $48 \mathrm{~h}$.

${ }^{7}$ Proportions of cows that ovulated one or more follicles by $48 \mathrm{~h}$ after the second GnRH injection of Ovsynch.

among treatments and pretreatment cycling status were made by $F$-tests resulting from ANOVA. Differences between more than 2 means were tested by $\chi^{2}$ within procedure GENMOD or by the PDIFF option in procedure GLM, when protected by a significant $(P \leq$ 0.05) $F$-test.

\section{RESULTS}

\section{Cycling Status}

Numbers of cows and their DIM at TAI differed $(P<$ 0.01) among locations (Table 1). Treatment inseminations were made entirely at first service only at the Kansas location. Although service number varied at all other locations as indicated by the mean and standard deviation for DIM (Table 1), 79\% of cows at all locations were inseminated before 100 DIM.

Proportions of cows cycling before onset of treatments ranged from 41 to $94 \%$ and differed $(P<0.001)$ among locations (Table 1). Lactation number, DIM, and milk yield, however, did not influence the proportions of cows cycling before onset of treatments. Percentages of cycling $(72 \%)$ and noncycling (70\%) cows subsequently treated with OVS or OVS + CIDR were similar (see footnote 2 in Table 1 for distribution of cows in each location).

\section{Pregnancy Outcomes}

The primary objective of this study was to determine whether P4 supplementation from a 1.9-g CIDR insert before AI would increase conception rates in lactating dairy cows. The design of this study also allowed determination of the effect of pretreatment cycling status with the CIDR insert on fertility in cycling and noncycling cows, as well as its effect on cows having an active CL (high P4) before the $\mathrm{PGF}_{2 \alpha}$ injection.

As a result of the CIDR insert, pregnancy outcomes at $\mathrm{d} 28$ after TAI were improved $(P<0.05)$ by 10 percentage points (Table 2 ). Inconsistencies in pregnancy outcomes among locations $(P<0.05)$, however, accounted for an interaction $(P<0.05)$ of treatment $\times$ location at d 28 and 56. In response to P4 treatment via the CIDR insert, cows in Illinois, Kansas, Missouri, and Ohio had numerically greater conception rates at $\mathrm{d} 28$, and also at d 56 (except in Missouri); cows in Michigan and Wisconsin had poorer conception rates at $\mathrm{d} 28$ and 56 .

Even though 4 locations (Illinois, Kansas, Missouri, and Ohio) had overall numerically greater conception rates in response to the CIDR insert, neither DIM nor cycling status accounted for these similarities (Table 1). At the extremes for DIM at TAI (least in Kansas and most in Illinois) and pretreatment cycling status (least in Kansas and most in Illinois), conception rates were the greatest at both locations (Tables 1 and 2). For cows in Missouri and Ohio, pretreatment cycling status and DIM at TAI were intermediate between the extremes for Illinois and Kansas, but both locations had numerical advantages for conception rates.

In an attempt to explain the treatment $\times$ location interaction on pregnancy outcomes, pretreatment cy- 
Table 2. Conception rates in lactating dairy cows at 28 and $56 \mathrm{~d}$ after timed AI in response to Ovsynch (OVS) or Ovsynch + controlled internal drug release (CIDR) insert (OVS + CIDR), and subsequent pregnancy losses from d 28 to 56

\begin{tabular}{|c|c|c|c|c|c|c|c|c|c|}
\hline \multirow[b]{2}{*}{ Location } & \multicolumn{3}{|c|}{ Pregnant at $28 \mathrm{~d}^{1}$} & \multicolumn{3}{|c|}{ Pregnant at $56 \mathrm{~d}^{2}$} & \multicolumn{3}{|c|}{$\begin{array}{l}\text { Pregnancy } \operatorname{loss}^{3} \\
28 \text { to } 56 \mathrm{~d}\end{array}$} \\
\hline & $\begin{array}{l}\text { No. of } \\
\text { cows }\end{array}$ & OVS & $\begin{array}{l}\text { OVS + } \\
\text { CIDR }\end{array}$ & $\begin{array}{l}\text { No. of } \\
\text { cows }\end{array}$ & OVS & $\begin{array}{l}\text { OVS + } \\
\text { CIDR }\end{array}$ & $\begin{array}{l}\text { No. of } \\
\text { cows }\end{array}$ & OVS & $\begin{array}{l}\text { OVS + } \\
\text { CIDR }\end{array}$ \\
\hline & & & 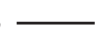 & & 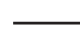 & 6 & & $\longrightarrow$ & - \\
\hline IL & 96 & 44 & 72 & 96 & 30 & 48 & 58 & 30 & 36 \\
\hline $\mathrm{KS}$ & 184 & 38 & 62 & 184 & 24 & 51 & 86 & 41 & 17 \\
\hline MI & 94 & 40 & 33 & 94 & 31 & 25 & 36 & 23 & 14 \\
\hline MO & 99 & 40 & 44 & 99 & 39 & 38 & 42 & 5 & 10 \\
\hline $\mathrm{OH}$ & 93 & 25 & 41 & 93 & 24 & 30 & 32 & 10 & 28 \\
\hline WI & 68 & 56 & 49 & 68 & 47 & 37 & 35 & 18 & 25 \\
\hline Average & & 40 & 50 & & 33 & 38 & & 21 & 21 \\
\hline
\end{tabular}

${ }^{1}$ Treatment $(P<0.05)$, location $(P<0.01)$, and treatment $\times$ location interaction $(P<0.05)$.

${ }^{2}$ Treatment $\times$ location interaction $(P<0.05)$.

${ }^{3}$ Location $(P<0.05)$ and treatment $\times$ location interaction $(P=0.09)$.

cling status was examined, in addition to whether serum $\mathrm{P} 4$ was high or low before $\mathrm{PGF}_{2 \alpha}$ was administered. In other words, cows were categorized by pretreatment cycling status and luteal status before the $\mathrm{PGF}_{2 \alpha}$ injection (Table 3). Across treatments, conception rates at $56 \mathrm{~d}$ after TAI in 184 noncycling cows $(31 \%)$ did not differ from those of 450 cycling cows (35\%). Of the 184 noncycling cows in which serum $\mathrm{P} 4$ was low before treatment, $57 \%$ of the cows had high $\mathrm{P} 4$ before the $\mathrm{PGF}_{2 \alpha}$ injection, whereas $79 \%$ of 450 cycling cows had high $\mathrm{P} 4$ before the $\mathrm{PGF}_{2 \alpha}$ injection (Table 3).

It is clear, however, that cycling cows having an active $\mathrm{CL}(\mathrm{OVS}=39 \%$ vs. OVS $+\mathrm{CIDR}=43 \%)$ and noncycling cows having an active induced CL $(\mathrm{OVS}=39 \%$ vs. OVS= CIDR $=34 \%$ ) did not have improved conception rates at $\mathrm{d} 56$ in response to additional $\mathrm{P} 4$ provided by the CIDR insert, respectively (Table 3 ).
In contrast, the treatment $\times$ luteal status interaction $(P<0.05)$ indicated that regardless of pretreatment cycling status, noncycling cows treated with a CIDR insert without an active induced CL (OVS + CIDR = $33 \%$ vs. OVS $=17 \%$ ) or cycling cows without an active $\mathrm{CL}(\mathrm{OVS}+\mathrm{CIDR}=38$ vs. OVS $=19 \%)$ before the $\mathrm{PGF}_{2 \alpha}$ injection had greater conception rates than OVS cows of similar luteal status.

\section{Pregnancy Losses}

Pregnancy loss between 28 and $56 \mathrm{~d}$ after TAI did not differ between treatments (Table 2), but effects of location $(P<0.05)$ and a tendency $(P=0.09)$ for a treatment $\times$ location interaction were detected. Although OVS + CIDR cows in Kansas and Michigan seemed to have fewer pregnancy losses than OVS cows, those at

Table 3. Conception rates in lactating dairy cows at $56 \mathrm{~d}$ after timed AI based on cycling status before treatment and on serum concentrations of progesterone $(\mathrm{P} 4)$ at the time of $\mathrm{PGF}_{2 \alpha}$ injection of the Ovsynch (OVS) or Ovsynch + controlled internal drug release (CIDR) insert (OVS + CIDR) protocol

\begin{tabular}{|c|c|c|c|c|c|}
\hline \multirow{2}{*}{$\begin{array}{l}\text { Pretreatment } \\
\text { cycling status }\end{array}$} & \multirow{2}{*}{$\begin{array}{l}\text { Serum P4 } \\
\text { before PGF }{ }_{2 \alpha}{ }^{1}\end{array}$} & \multirow{2}{*}{$\begin{array}{l}\text { Luteal status } \\
\text { before } \text { PGF }_{2 \alpha}\end{array}$} & \multicolumn{2}{|c|}{ Treatment $^{2}$} & \multirow[b]{2}{*}{ Total $^{3}$} \\
\hline & & & Ovs & OVS + CIDR & \\
\hline & & & & $\%$ (no. of cows) & \\
\hline \multirow{2}{*}{ Noncycling } & High & $\begin{array}{l}\text { Active induced corpus } \\
\text { luteum }(\mathrm{CL})^{4}\end{array}$ & $39(58)$ & $34(47)$ & $37(105)$ \\
\hline & Low & No induced $\mathrm{CL}^{4}$ & $17(38)$ & 33 (41) & $25(79)$ \\
\hline \multirow[t]{2}{*}{ Cycling } & High & Active CL & 39 (178) & 43 (179) & $41(357)$ \\
\hline & Low & Early luteolysis & $19(47)$ & $38(46)$ & $28(93)$ \\
\hline \multirow[t]{2}{*}{ Total } & High & Active CL & $39(236)$ & $39(226)$ & \\
\hline & Low & No CL & $18(85)$ & $36(87)$ & \\
\hline
\end{tabular}

\footnotetext{
${ }^{1} \mathrm{PGF}_{2 \alpha}$ injection given before timed AI. High $=\geq 1 \mathrm{ng} / \mathrm{mL}$ and low $=<1 \mathrm{ng} / \mathrm{mL}$.

${ }^{2}$ Two-way interaction $(P<0.05)$ of treatment $\times$ luteal status before $\mathrm{PGF}_{2 \alpha}$. No three-way interaction of treatment $\times$ pretreatment cycling status $\times$ luteal status before $\mathrm{PGF}_{2 \alpha}$.

${ }^{3}$ Conception rate in 184 noncycling cows $(31 \%)$ did not differ from that of 450 cycling cows (35\%).

${ }^{4}$ In response to the first GnRH injection.
} 
Table 4. Pregnancy loss in lactating dairy cows from 28 to $56 \mathrm{~d}$ after timed AI, based on cycling status before treatment and on serum concentrations of progesterone (P4) at the time the $\mathrm{PGF}_{2 \alpha}$ injection of the Ovsynch (OVS) or Ovsynch + controlled internal drug release (CIDR) insert (OVS + CIDR) protocol

\begin{tabular}{|c|c|c|c|c|c|}
\hline \multirow{2}{*}{$\begin{array}{l}\text { Pretreatment } \\
\text { cycling status }\end{array}$} & \multirow{2}{*}{$\begin{array}{l}\text { Serum P4 } \\
\text { before } \\
\text { PGF }_{2 \alpha}{ }^{1}\end{array}$} & \multirow{2}{*}{$\begin{array}{l}\text { Luteal status } \\
\text { before } \mathrm{PGF}_{2 \alpha}\end{array}$} & \multicolumn{2}{|c|}{ Treatment $^{2}$} & \multirow[b]{2}{*}{ Total $^{3}$} \\
\hline & & & OVS & OVS + CIDR & \\
\hline & & & & $\%$ (no. of cows) & \\
\hline \multirow[t]{2}{*}{ Noncycling } & High & Active induced corpus luteum (CL) ${ }^{4}$ & $18(25)$ & $38(28)$ & $29(53)$ \\
\hline & Low & No induced $\mathrm{CL}^{4}$ & $42(8)$ & $24(20)$ & $29(28)$ \\
\hline \multirow[t]{2}{*}{ Cycling } & High & Active CL & $15(81)$ & $12(91)$ & $13(172)$ \\
\hline & Low & Early luteolysis & $34(16)$ & $5(20)$ & $18(36)$ \\
\hline \multirow[t]{2}{*}{ Total } & High & Active CL & $17(106)$ & 25 (119) & \\
\hline & Low & No CL & $38(24)$ & $14(40)$ & \\
\hline
\end{tabular}

\footnotetext{
${ }^{1} \mathrm{PGF}_{2 \alpha}$ injection given before timed AI. High $=\geq 1 \mathrm{ng} / \mathrm{mL}$ and low $=<1 \mathrm{ng} / \mathrm{mL}$.

${ }^{2}$ Two-way interaction $(P<0.01)$ of treatment $\times$ luteal status before $\mathrm{PGF}_{2 \alpha}$. No three-way interaction of treatment $\times$ pretreatment cycling status $\times$ luteal status before $\mathrm{PGF}_{2 \alpha}$.

${ }^{3}$ Pregnancy loss in 81 noncycling cows $(31 \%)$ differed $(P<0.05)$ from loss in 208 cycling cows $(16 \%)$.

${ }^{4}$ In response to the first GnRH injection.
}

other locations had numerically greater losses between 28 and $56 \mathrm{~d}$ after TAI in response to $\mathrm{P} 4$ supplementation (Table 2).

Accounting for pretreatment cycling status of cows, and whether an active CL was present before $\mathrm{PGF}_{2 \alpha}$ was administered, did not eliminate the location or treatment $\times$ location effects (Table 4 ). Noncycling cows $(31 \% ; \mathrm{n}=81)$, however, had greater $(P<0.05)$ pregnancy loss than that for cycling cows $(16 \% ; n=208)$. Although pregnancy losses were greater for cows classified as noncycling, overall losses were reduced for all cows receiving CIDR inserts when serum $\mathrm{P} 4$ was low before $\mathrm{PGF}_{2 \alpha}$ in noncycling cows without an induced CL (OVS + CIDR $=24 \%$ vs. OVS $=42 \%$ ) and in cycling cows without an active CL (OVS + CIDR $=5 \%$ vs. OVS = $34 \%$ ) before the $\mathrm{PGF}_{2 \alpha}$ injection (Table 4). In contrast, the interaction $(P<0.01)$ of treatment $\times$ serum $\mathrm{P} 4$ status before $\mathrm{PGF}_{2 \alpha}$ injection showed that pregnancy loss was greater in OVS + CIDR than in OVS when serum P4 was high (25 vs. 17\%), regardless of pretreatment cycling status.

\section{Concentrations of P4 at CIDR Insert Removal}

Supplementing P4 via the CIDR insert did not increase relative serum concentrations of $\mathrm{P} 4$ in cows. Concentrations of $\mathrm{P} 4$ measured in blood samples collected just before CIDR insert removal at 2 locations did not differ between OVS $(2.2 \pm 0.3 \mathrm{ng} / \mathrm{mL} ; \mathrm{n}=84)$ and OVS + CIDR cows $(2.4 \pm 0.3 \mathrm{ng} / \mathrm{mL} ; \mathrm{n}=80)$. Just before CIDR insert removal, concentrations of $\mathrm{P} 4$ in 19 noncycling CIDR-treated cows $(1.9 \pm 0.6 \mathrm{ng} / \mathrm{mL})$ did not differ from those of 16 noncycling OVS $(1.8 \pm 0.5 \mathrm{ng} / \mathrm{mL})$. Likewise, at CIDR insert removal, concentrations of $\mathrm{P} 4$ were similar among 71 cycling OVS cows $(2.8 \pm 0.2 \mathrm{ng} / \mathrm{mL})$ and
68 cycling cows treated with CIDR inserts $(2.7 \pm 0.2$ $\mathrm{ng} / \mathrm{mL}$ ).

\section{Induced Ovulation in Noncycling Cows}

Concentrations of $\mathrm{P} 4$ exceeded $1 \mathrm{ng} / \mathrm{mL}$ in some noncycling cows because of $\mathrm{P} 4$ supplementation provided by the CIDR insert and because $57 \%$ of all noncycling cows (54\% at the 2 sampled locations) ovulated in response to the first GnRH injection. After the first GnRH injection, ovulation was induced in 52 to $83 \%$ of all noncycling cows. Proportions of cows having induced ovulation did not differ among locations (Table 1).

\section{Concentrations of P4 Before PGF Injection $_{2 \alpha}$}

Decline in concentrations of $\mathrm{P} 4$ for cows treated with a CIDR insert between the time of insert removal and 1 to $2 \mathrm{~h}$ later when the $\mathrm{PGF}_{2 \alpha}$ injection was given averaged only $0.5 \pm 0.1 \mathrm{ng} / \mathrm{mL}$, ranged from $-0.2 \pm 0.1$ to $0.8 \pm 0.1 \mathrm{ng} / \mathrm{mL}$ among locations. These differences in P4 suggested that the P4 contribution of the CIDR insert to peripheral serum concentrations of $\mathrm{P} 4$ was small. When $\mathrm{P} 4$ was assessed in blood samples collected before $\mathrm{PGF}_{2 \alpha}$ injection from cows at all locations at least $1 \mathrm{~h}$ after CIDR insert removal, OVS + CIDR cows (2.4 $\pm 0.2 \mathrm{ng} / \mathrm{mL} ; \mathrm{n}=313)$ did not differ from OVS (2.5 \pm $0.2 \mathrm{ng} / \mathrm{mL} ; \mathrm{n}=321$ ). Cycling cows had greater concentrations of $\mathrm{P} 4(3.3 \pm 0.1 \mathrm{ng} / \mathrm{mL} ; \mathrm{n}=450)$ than noncycling cows $(1.6 \pm 0.2 \mathrm{ng} / \mathrm{mL} ; \mathrm{n}=184)$. Concentrations of $\mathrm{P} 4$ exceeded $1 \mathrm{ng} / \mathrm{mL}$ in noncycling cows because cycling status was determined before treatment. Therefore, some cows classified as noncycling had ovulated in response to the first GnRH injection (Table 1) and had elevated serum P4 during and after the time of CIDR insert removal. 
Table 5. Diameter of the ovulatory follicle before the second GnRH injection of the Ovsynch (OVS) or Ovsynch + controlled internal drug release (CIDR) insert (OVS + CIDR) protocol, based on cycling status before treatment and on serum concentrations of progesterone $(\mathrm{P} 4)$ at the time of $\mathrm{PGF}_{2 \alpha}$ injection

\begin{tabular}{|c|c|c|c|c|}
\hline \multirow{2}{*}{$\begin{array}{l}\text { Pretreatment } \\
\text { cycling status }\end{array}$} & \multirow{2}{*}{$\begin{array}{l}\text { Serum P4 } \\
\text { before } \\
\text { PGF }_{2 \alpha}{ }^{1}\end{array}$} & \multirow{2}{*}{$\begin{array}{l}\text { Luteal status } \\
\text { before } \mathrm{PGF}_{2 \alpha}\end{array}$} & \multicolumn{2}{|c|}{ Treatment ${ }^{2}$} \\
\hline & & & OVs & OVS + CIDR \\
\hline & & & $\longrightarrow$ Mean $\pm \mathrm{SE}$ & no. of cows) \\
\hline \multirow[t]{2}{*}{ Noncycling } & High & Active induced corpus luteum (CL) ${ }^{4}$ & $15.5 \pm 0.4(47)$ & $16.4 \pm 0.4(39)$ \\
\hline & Low & No induced $\mathrm{CL}^{4}$ & $14.2 \pm 0.5(27)$ & $15.5 \pm 0.5(31)$ \\
\hline \multirow[t]{2}{*}{ Cycling } & High & Active CL & $14.9 \pm 0.2(154)$ & $14.8 \pm 0.2(160)$ \\
\hline & Low & Early luteolysis & $14.9 \pm 0.4(40)$ & $16.3 \pm 0.4(41)$ \\
\hline
\end{tabular}

${ }^{1} \mathrm{PGF}_{2 \alpha}$ injection given before timed AI. High $=\geq 1 \mathrm{ng} / \mathrm{mL}$ and low $=<1 \mathrm{ng} / \mathrm{mL}$.

${ }^{2}$ Three-way interaction $(P<0.01)$ of treatment $\times$ pretreatment cycling status before treatment $\times$ luteal status before $\mathrm{PGF}_{2 \alpha}$.

${ }^{3}$ Follicle diameter in noncycling cows $(15.4 \pm 0.3 \mathrm{~mm} ; \mathrm{n}=144)$ did not differ from that of cycling cows (15.2 $\pm 0.2 \mathrm{~mm} ; \mathrm{n}=395)$.

${ }^{4}$ In response to the first GnRH injection.

Percentages of cows in which concentrations of $\mathrm{P} 4$ were $\geq 1 \mathrm{ng} / \mathrm{mL}$ before the $\mathrm{PGF}_{2 \alpha}$ injection ranged from 63 to $84 \%$ among locations (Table 1$)$ and differed $(P=$ $0.05)$ among locations. Fewer $(P<0.001)$ noncycling cows $(58 \% ; \mathrm{n}=168)$ than cycling cows $(79 \% ; \mathrm{n}=434)$ had high $\mathrm{P} 4$ before $\mathrm{PGF}_{2 \alpha}$ injection.

\section{Concentrations of $P 4$ after $P G F_{2 \alpha}$ Injection}

Proportions of all cows in which serum $\mathrm{P} 4$ approached basal (proestrus) concentrations by $48 \mathrm{~h}$ after $\mathrm{PGF}_{2 \alpha}$ were affected by treatment differently at various locations (treatment $\times$ location interaction; $P<0.001$; Table 1). Among OVS + CIDR cows, the percentages ranged from 83 to 99\%, whereas among OVS, they ranged from 79 to $100 \%$. Although differences were small, at 3 locations, more OVS + CIDR cows than OVS cows had low $\mathrm{P} 4$, whereas the reverse was true at 3 other locations. Interactions were unrelated to overall cycling status at each location, but more $(P<0.05)$ noncycling cows $(97 \%$; $\mathrm{n}=184)$ than cycling cows $(92 \% ; \mathrm{n}=447)$ had low $\mathrm{P} 4$ by $48 \mathrm{~h}$ after $\mathrm{PGF}_{2 \alpha}$ injection. Proportion of cows undergoing CL regression followed the same trends as percentages of cows having low $\mathrm{P} 4$ by $48 \mathrm{~h}$ after $\mathrm{PGF}_{2 \alpha}$ injection (Table 1).

\section{Ovulatory Responses}

Incidence of ovulation in 602 cows examined by $48 \mathrm{~h}$ after the second GnRH injection ranged from 85 to $95 \%$, but did not differ among locations (Table 1). More cycling cows $(91 \% ; \mathrm{n}=434)$ than noncycling cows $(84 \%$; $\mathrm{n}=168$ ) ovulated at least 1 follicle. Proportion of cows having multiple ovulations was not affected by location (Table 1). Multiple ovulations occurred less $(P<0.05)$ frequently in 434 cycling than 168 noncycling cows (7.9 vs. $15.2 \%$; respectively).

\section{Follicle Size}

Of 602 cows examined for follicular diameters and evidence of ovulation, only 2 cows failed to ovulate when at least 1 follicle was identified $>5 \mathrm{~mm}$ in diameter. The remaining 62 cows failed to have at least 1 follicle in excess of $5 \mathrm{~mm}$ in diameter and did not ovulate. Overall, cows treated with $\mathrm{P} 4$ had larger $(P<0.01)$ follicles than did cows not treated with P4 [(15.7 \pm 0.2 $\mathrm{mm}, \mathrm{n}=271)$ vs. $(15.1 \pm 0.2 \mathrm{~mm}, \mathrm{n}=268)$; Table 5], but a 3 -way interaction $(P<0.01)$ between treatment, luteal status before $\mathrm{PGF}_{2 \alpha}$, and pretreatment cycling status was detected. In 3 of the 4 treatment contrasts in Table 5, CIDR-treated cows had larger follicles, except in cycling cows having an active CL (high $\mathrm{P} 4$ ) before $\mathrm{PGF}_{2 \alpha}$ injection.

No relationship was detected between follicular size and conception rates. Across treatments, however, pregnancy loss between $\mathrm{d} 28$ and 56 tended $(P=0.08)$ to be greater when follicle diameter was $\leq 15 \mathrm{~mm}$ (27\%; $\mathrm{n}=134)$ than when $>15 \mathrm{~mm}(18 \% ; \mathrm{n}=134)$.

\section{Multiple Ovulations}

Incidence of multiple ovulations assessed in 602 cows averaged $10.3 \%$, ranged from 5.1 to $14.9 \%$ across locations, but did not differ among locations (Table 1). Noncycling cows had greater incidences of multiple ovulations $(15.2 \% ; \mathrm{n}=168)$ than cycling cows $(5.7 \% ; \mathrm{n}=434)$. The incidence of multiple ovulations based on luteal status before the $\mathrm{PGF}_{2 \alpha}$ injection is summarized by treatment in Table 6. No treatment interactions were detected.

Conception rates were greater $(P<0.01)$ at $28 \mathrm{~d}(68$ vs. $42 \%)$ and $56 \mathrm{~d}$ (53 vs. $34 \%)$ after TAI for cows having multiple $(\mathrm{n}=62)$ vs. single $(\mathrm{n}=540)$ ovulation, respectively. Pregnancy loss tended to be greater in OVS cows 
Table 6. Incidence of multiple ovulation $48 \mathrm{~h}$ after the second GnRH injection of the Ovsynch (OVS) or Ovsynch + controlled internal drug release (CIDR) insert (OVS + CIDR) protocol, based on ovulatory status before treatment and on serum concentrations of progesterone $(\mathrm{P} 4)$ at the time of $\mathrm{PGF}_{2 \alpha}$ injection

\begin{tabular}{|c|c|c|c|c|c|}
\hline \multirow{2}{*}{$\begin{array}{l}\text { Pretreatment } \\
\text { cycling status }\end{array}$} & \multirow{2}{*}{$\begin{array}{l}\text { Serum P4 } \\
\text { before } \\
\text { PGF }_{2 \alpha}{ }^{1}\end{array}$} & \multirow{2}{*}{$\begin{array}{l}\text { Luteal status } \\
\text { before } \mathrm{PGF}_{2 \alpha}\end{array}$} & \multicolumn{2}{|c|}{ Treatment $^{2}$} & \multirow[b]{2}{*}{ Total $^{3}$} \\
\hline & & & OVS & OVS + CIDR & \\
\hline & & & & $\%$ (no. of cows) & \\
\hline \multirow[t]{2}{*}{ Noncycling } & High & Active induced corpus luteum $(\mathrm{CL})^{4}$ & $15.4(51)$ & $14.9(43)$ & $15.2(94)$ \\
\hline & Low & No induced $\mathrm{CL}^{4}$ & $16.5(38)$ & $14.2(36)$ & $15.3(74)$ \\
\hline \multirow[t]{2}{*}{ Cycling } & High & Active CL & $7.1(169)$ & $11.8(175)$ & $9.5(344)$ \\
\hline & Low & Early luteolysis & $0.0(46)$ & $5.7(44)$ & $1.9(90)$ \\
\hline
\end{tabular}

${ }^{1} \mathrm{PGF}_{2 \alpha}$ injection given before timed AI. High $=\geq 1 \mathrm{ng} / \mathrm{mL}$ and low $=<1 \mathrm{ng} / \mathrm{mL}$.

${ }^{2}$ No treatment interactions.

${ }^{3}$ Incidence of multiple ovulation in 168 noncycling cows $(15.2 \%)$ differed $(P<0.01)$ from incidence in 434 cycling cows $(5.7 \%)$.

${ }^{4}$ In response to the first $\mathrm{GnRH}$ injection.

having multiple $(31 \% ; \mathrm{n}=18)$ vs. single $(19 \% ; \mathrm{n}=106)$ ovulation, whereas the reverse trend was detected for OVS+CIDR cows $(15 \%, \mathrm{n}=24$; vs. $26 \%, \mathrm{n}=129)$, respectively, (treatment $\times$ multiple ovulation; $P=0.08$ ).

\section{DISCUSSION}

The objective of our study was to determine whether P4 supplementation from a 1.9-g CIDR insert before TAI, as part of the Ovsynch protocol, would improve fertility. Overall, compared with OVS, conception rates were 10 and 5 percentage points greater for cows treated with $\mathrm{P} 4$ at 28 and $56 \mathrm{~d}$ after TAI, respectively. Conception rates were positive for both cycling and noncycling cows treated with the CIDR insert, but only at 4 of the 6 locations at $28 \mathrm{~d}$ and at 3 of 6 locations at 56 $\mathrm{d}$. This inconsistent response is corroborated by other large-scale studies summarized from the literature in Table 7. In one study, conception rates were improved by addition of a CIDR insert (El-Zarkouny et al., 2004) compared with cows inseminated at estrus or after the Ovsynch protocol. In a 5-location study conducted during summer in Mexico, in which cows were treated with Ovsynch alone, conception rates were only improved in first-lactation cows in which a CIDR insert also was included (Moreira et al., 2004a).

In another study conducted in Mexico, in which estrous cycles were presynchronized (Presynch) in all cows before treatment with Ovsynch, addition of a CIDR insert improved conception rates (Moreira et al., 2004b), whereas no positive effect occurred in 2 other studies of similar treatments (El-Zarkouny et al., 2004; Thatcher et al., 2006), unless cows were in late diestrus at the time of CIDR insertion (Thatcher et al., 2006). In another large study, estrous cycles were presynchronized (Presynch) and a CIDR insert was incorporated into a TAI protocol using estradiol cypionate to induce estrus and ovulation (Galvão et al., 2004). Conception rate in lactating dairy cows was not improved in response to the CIDR insert; however, few noncycling cows received a CIDR insert $(n=52)$.

In the present study, blood $\mathrm{P} 4$ concentrations at time of $\mathrm{PGF}_{2 \alpha}$ injection influenced conception rates (Table 3 ). Cows having low serum $\mathrm{P} 4$ before the $\mathrm{PGF}_{2 \alpha}$ injection, whether cycling or not, had greater conception rates when treated with a CIDR insert. Noncycling cows in which an active CL was induced and cycling cows having an active $\mathrm{CL}$ at the time of $\mathrm{PGF}_{2 \alpha}$ injection did not have improved conception rates as a result of $\mathrm{P} 4$ supplementation. Therefore, only cows without an active CL before $\mathrm{PGF}_{2 \alpha}$ injection had improved pregnancy outcomes. Our hypothesis was that noncycling cows and cycling cows having low $\mathrm{P} 4$ before the $\mathrm{PGF}_{2 \alpha}$ injection should have improved conception rates when treated with the Ovsynch protocol in combination with the CIDR insert. Not all results to date confirm that hypothesis.

The mechanism by which conception rates were improved in CIDR-treated cows having low $\mathrm{P} 4$ before the $\mathrm{PGF}_{2 \alpha}$ injection may include several possibilities. A lack of synchrony between luteolysis, ovulation, and TAI for cycling OVS cows having early luteolysis may have been remedied in part by the CIDR insert because estrus and ovulation were prevented by the supplemental P4. Our results are consistent with improved conception rates for similarly treated cycling suckled beef cows in which blood $\mathrm{P} 4$ was low before $\mathrm{PGF}_{2 \alpha}$ injection (Lamb et al., 2001).

For noncycling cows in which no CL was induced and serum $\mathrm{P} 4$ was low before the $\mathrm{PGF}_{2 \alpha}$ injection (Table 3), conception rates were increased in OVS+CIDR cows. Our results corroborate at least 3 other studies in beef cattle (Lamb et al., 2001; Stevenson et al., 2003; Larson et al., 2006), in which use of the CIDR insert improved conception rates in noncycling cows without an induced $\mathrm{CL}$. It is possible that the supplemental P4 served a 
Table 7. Studies from the literature in which Ovsynch or Presynch + Ovsynch in combination were compared with similar treatments that included an intravaginal progesterone-releasing controlled interval drug release (CIDR) insert in lactating dairy cows

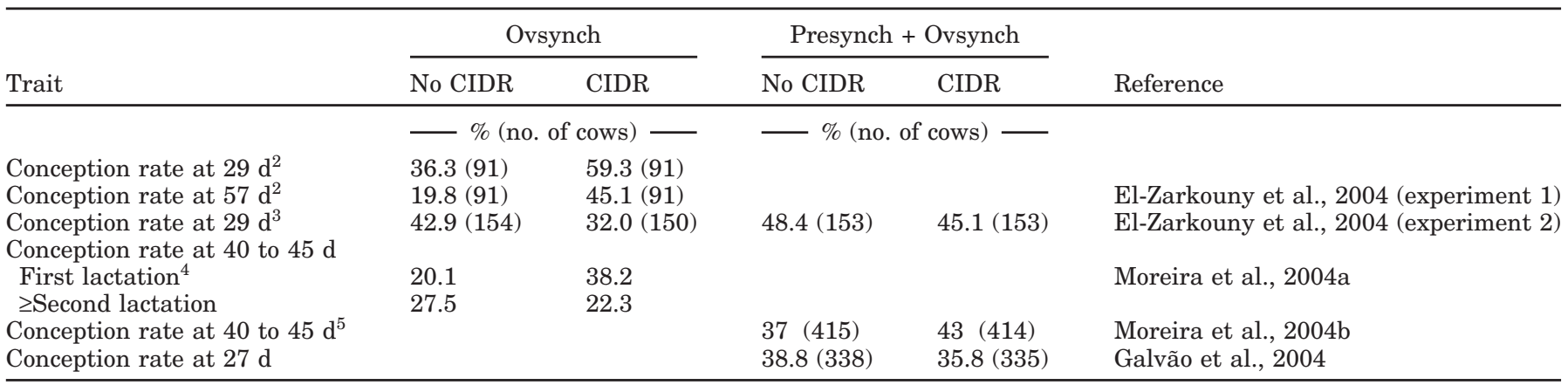

${ }^{1}$ Greater $(P<0.05)$ conception rates for cows treated with CIDR inserts having no CL before the PGF ${ }_{2 \alpha}$ injection.

${ }^{2}$ Greater $(P<0.05)$ conception rates for Ovsynch cows treated with a CIDR insert.

${ }^{3}$ Greater $(P<0.05)$ conception rates for Presynch cows; no effect of CIDR insert.

${ }^{4}$ Greater $(P<0.05)$ conception rates for CIDR-treated first-lactation cows only.

${ }^{5}$ Greater $(P<0.05)$ conception rates for Presynch + Ovsynch cows treated with CIDR inserts.

priming function to facilitate ovulation of a follicle in response to the second GnRH injection. In suckled noncycling beef cows treated with $\mathrm{GnRH}+$ norgestomet (analogous to the first GnRH + CIDR insert in our study), size of the recruited follicle after GnRH was not increased, but greater subsequent concentrations of estradiol enhanced the GnRH-induced LH release at $48 \mathrm{~h}$ after $\mathrm{PGF}_{2 \alpha}$ and increased the occurrence of normal luteal function after induced ovulation (Thompson et al., 1999). In a recent study, a greater proportion of anovulatory lactating dairy cows treated with a CIDR insert had high P4 by $62 \pm 7$ DIM compared with controls (Cerri et al., 2005). Factors influencing why the CIDR was beneficial in some, but not all, anestrous cows need to be identified.

Concentrations of P4 in cows with or without an active CL were only slightly increased by the CIDR insert in the present study. Other studies in beef cattle concluded that the CIDR insert provided relatively small increases $(0.5$ to $1 \mathrm{ng} / \mathrm{mL})$ in serum concentrations of P4 (Stevenson et al., 2003). Endogenous P4 production was decreased by insertion of a P4-releasing intravaginal device in late diestrus (d 10 to 17), whereas no change occurred when treatment was initiated earlier, on $\mathrm{d} 5$ to 10 of the estrous cycle (Robinson et al., 1989). These observations are consistent with the concept that the CL has receptors for P4 (Schams and Berisha, 2002) allowing for some self-autoregulation of P4 biosynthesis, and thus partly influencing peripheral P4 concentrations, in addition to liver-regulated clearance rates of P4 (Sangsritavong et al., 2002)

Further, initiating $\mathrm{P} 4$ treatment (P4-releasing intravaginal device) during the luteal phase increased conception rates in cows having reduced $\mathrm{P} 4$ concentrations, but decreased conception rates in cows having greater
P4 concentrations (Folman et al., 1990). Therefore, P4 treatment may have improved fertility in cows with low peripheral $\mathrm{P} 4$ concentrations during the luteal phase (e.g., starting treatment in late diestrus; Thatcher et al., 2006), or when treatment was started earlier during the luteal phase of the estrous cycle. Our results (Table 3) are consistent with those reported by Folman et al. (1990) in which a P4-releasing intravaginal device was used.

Other studies demonstrated that heifers had greater fertility (Pursley et al., 1997) and greater blood concentrations of P4 (Wiltbank et al., 2000; Wolfenson et al., 2004) during the estrous cycle than did lactating dairy cows. If subnormal P4 concentrations were limiting fertility of lactating dairy cows, it would seem logical that conception rates in cycling cows might increase in response to CIDR inserts. Concentrations of P4, however, at the time of CIDR removal did not differ between treatments. Because blood samples were not collected each day the CIDR was in situ, we cannot determine whether P4 was significantly altered during the treatment period. In suckled beef cows in which ovulation was induced after treatment with $\mathrm{GnRH}$ and norgestomet, serum concentrations of $\mathrm{P} 4$ were greater after 7 d compared with cows treated with GnRH alone (Thompson et al., 1999), although their peak increase rarely exceeded $1.5 \mathrm{ng} / \mathrm{mL}$ in previously noncycling cows. In the previous cases, cows had newly formed, induced CL in addition to an exogenous source of progestin. In 4 ovariectomized cows treated with 1.38 -g CIDR inserts, concentrations of $\mathrm{P} 4$ exceeded $5 \mathrm{ng} / \mathrm{mL}$ by $1 \mathrm{~h}$ after its insertion, but decreased linearly to about $2.8 \mathrm{ng} / \mathrm{mL}$ after $7 \mathrm{~d}$ (Rathbone et al., 2002). Concentrations of $\mathrm{P} 4$ decreased to 0.75 and $0.5 \mathrm{ng} / \mathrm{mL}$ by 1 and $2 \mathrm{~h}$, respectively, after insert removal. It is not clear 
how the CIDR insert affects circulating concentrations of $\mathrm{P} 4$ in cycling cows at different stages of the estrous cycle. In the current study, regardless of treatment, no trend was detected for increased conception rate when endogenous P4 was high at the time of insert removal. Perhaps duration of exposure to $\mathrm{P} 4$ during the week before $\mathrm{PGF}_{2 \alpha}$ injection is more important than the absolute magnitude of $\mathrm{P} 4$ concentrations in serum.

Diameters of the follicles detected before the second GnRH injection were greater for all cows treated with the CIDR insert, except for cycling cows having an active CL before luteolysis was induced (Table 5). Because concentrations of $\mathrm{P} 4$ were less in noncycling cows, regardless of luteal status before the before $\mathrm{PGF}_{2 \alpha}$ injection, and in cycling cows in which early luteolysis occurred, supplemental P4 probably caused more rapid follicular growth while the CIDR insert was in situ. Without a normally functioning CL that produces luteal phase concentrations of $\mathrm{P} 4$, one would expect $\mathrm{LH}$ pulse frequency to increase and cause more rapid follicular maturation and increased diameters in all cows relative to those in which an active CL is present (Smith and Stevenson, 1995). Our results for follicle diameters in cows treated with a CIDR insert are consistent with that observation.

Pregnancy losses between 28 and $56 \mathrm{~d}$ after TAI were greater in noncycling cows and were not affected by treatment, except when cows had low $\mathrm{P} 4$ before $\mathrm{PGF}_{2 \alpha}$ injection. Our results are consistent with a recent report summarizing 6,123 lactating dairy cows from 9 studies on 5 dairy farms (Rutigliano and Santos, 2005). They reported that pregnancy rates were greater for cycling than noncycling cows at $30 \mathrm{~d}$ (40 vs. $28 \%$ ) and $58 \mathrm{~d}$ (34 vs. $22 \%$ ) after TAI, but pregnancy losses were greater in noncycling cows (19 vs. $14 \%$ ). The CIDR inserts applied in our study, however, reduced losses in cows having low $\mathrm{P} 4$ at time of $\mathrm{PGF}_{2 \alpha}$ (Table 4). For noncycling cows without an active $\mathrm{CL}$ at $\mathrm{PGF}_{2 \alpha}$, reduced losses may be associated with a greater percentage of normal luteal activity detected after induced ovulations in cows preceded by supplementation of norgestomet (Thompson et al., 1999). Pregnancy losses differed among locations with losses of $31.4 \%$ in Kansas and $10 \%$ in Missouri. Although Ovsynch has been speculated as a cause of increased embryonic loss in lactating dairy cows, embryonic loss from 31 to $45( \pm 3)$ d after AI was similar for cows receiving AI after removed tail chalk and for cows receiving TAI after Ovsynch (10.4 vs. 13.2\%; Chebel et al., 2004).

How pregnancy loss can be affected 28 to $56 \mathrm{~d}$ after conception in response to events that occur before AI is unclear. Smaller ovulatory follicles may predispose subsequently formed CL to have fewer luteal cells and secrete less P4. Pregnancy losses were twice as great among noncycling than cycling cows (Table 4). In cases in which the follicle was larger in OVS+CIDR than OVS cows (noncycling cows having no induced CL and cycling cows having early luteolysis), follicle diameters were greater and pregnancy losses were less (Tables 4 and 5). The reverse was true for cows having an active $\mathrm{CL}$ at $\mathrm{PGF}_{2 \alpha}$ injection, even though follicle diameters were increased in cows having an active induced CL by supplemental P4, but not when cycling cows had an active CL before $\mathrm{PGF}_{2 \alpha}$ injection. Because of the interaction between treatment and luteal status before $\mathrm{PGF}_{2 \alpha}$ administration, pregnancy losses were likely not associated with follicle diameter, but related to the lack of established estrous cycles before the onset of treatment. Because conception rates seemed to improve in all cows having reduced $\mathrm{P} 4$ just before $\mathrm{PGF}_{2 \alpha}$ injection (Table 3), with cycling cows having less loss than noncycling cows, the effects of $\mathrm{P} 4$ are more likely related to a mechanism involving both improved uterine function and earlier establishment of estrous cycles. We detected greater pregnancy loss for cows having follicles $\leq 15 \mathrm{~mm}$ compared with those $>15 \mathrm{~mm}$ in diameter. Reduced conception rates and increased embryonic mortality in beef cows were only observed when follicles were $\leq 11$ $\mathrm{mm}$ in diameter following TAI (Perry et al., 2005). In contrast, when inseminations occurred after detected estrus and spontaneous ovulation in that same study, follicle size was not a factor in reduced fertility.

In summary, fertility of lactating dairy cows is poor, and has decreased more than 50\% since 1970 (Butler and Smith, 1989). Improving fertility of lactating dairy cows is economically important to the dairy industry. Understanding the pharmacological impact of $\mathrm{P} 4$ supplementation on conception rates may lead to a better understanding of the physiological reasons for reduced fertility of lactating dairy cows. In the current study, the CIDR improved chances for conception and reduced pregnancy losses between 28 and $56 \mathrm{~d}$ after TAI in cows at some locations in which no luteal activity was detected before the $\mathrm{PGF}_{2 \alpha}$ injection, regardless of their pretreatment cycling status.

\section{ACKNOWLEDGMENTS}

The authors thank the following dairy producers for allowing us to use their cattle and facilities to conduct this research study: Buschur's Dairy, New Weston, OH; 4-Henry Dairy, West Liberty, OH; Meier Dairy, Palmer, KS; Nobis Dairy Farm, St. Johns, MI; and Nehl's Brothers Dairy, Juneau, WI. We greatly appreciated the expert ultrasonic assessment of cattle in Ohio by Cynthia Johnson and the excellent field and laboratory contributions of Ann Ottobre. 


\section{REFERENCES}

Butler, W. R., and R. D. Smith. 1989. Interrelationships between energy balance and postpartum reproductive function in dairy cattle. J. Dairy Sci. 72:767-783.

Cerri, R. L. A., R. G. S. Bruno, and J. E. P. Santos. 2005. Effect of pre-synchronization and resynchronization with CIDR on reproductive performance of lactating dairy cows. J. Dairy Sci. 88(Suppl. 1):86. (Abstr.)

Chebel, R. C., J. E. P. Santos, J. P. Reynolds, R. L. A. Cerri, S. O. Juchem, and M. Overton. 2004. Factors affecting conception rate after artificial insemination and pregnancy loss in lactating dairy cows. Anim. Reprod. Sci. 84:239-255.

Clapper, J. A., J. S. Ottobre, A. C. Ottobre, and D. L. Zartman. 1990. Estrual rise in body temperature in the bovine: I. Temporal relationships with serum patterns of reproductive hormones. Anim. Reprod. Sci. 23:89-98.

El-Zarkouny, S. Z., J. A. Cartmill, B. A. Hensley, and J. S. Stevenson. 2004. Presynchronization of estrous cycles before Ovsynch and progesterone in dairy cows: Ovulation, pregnancy rates, and embryo survival. J. Dairy Sci. 87:1024-1037.

Folman, Y., M. Kaim, Z. Herz, and M. Rosenberg. 1990. Comparison of methods for the synchronization of estrous cycles in dairy cows. 2. Effects of progesterone and parity on conception. J. Dairy Sci. 73:2817-2825.

Fonseca, F. A., J. H. Britt, B. T. McDaniel, J. C. Wilk, and A. H. Rakes. 1983. Reproductive traits of Holsteins and Jerseys. Effects of age, milk yield, and clinical abnormalities on involution of cervix and uterus, ovulation, estrous cycles, detection of estrus, conception rate, and days open. J. Dairy Sci. 66:1128-1147.

Galvão, K. N., J. E. P. Santos, S. O. Juchem, R. L. A. Cerri, A. C. Coscioni, and M. Villaseñor. 2004. Effect of addition of a progesterone intravaginal insert to a timed insemination protocol using estradiol cypionate on ovulation rate, pregnancy rate, and late embryonic loss in lactating dairy cows. J. Anim. Sci. 82:35083517.

Kesler, D. J., H. Khazali, and R. J. Favero. 1990. Quantification of steroids via a polymer linked second antibody enzyme immunoassay system: Methods of linking anti-rabbit IgG to poly(styrene). Pages 157-170 in Progress in Biomedical Polymers. C. G. Gebelein and R. L. Dunn, ed. Plenum Publishing, New York, NY.

Kirby, C. J., M. F. Smith, D. H. Keisler, and M. C. Lucy. 1997. Follicular formation in lactating dairy cows treated with sustained-release bovine somatotropin. J. Dairy Sci. 80:273-285.

Lamb, G. C., J. S. Stevenson, D. J. Kesler, H. A. Garverick, D. R. Brown, and B. E. Salfen. 2001. Inclusion of an intravaginal progesterone insert plus $\mathrm{GnRH}$ and prostaglandin $\mathrm{F}_{2 \alpha}$ for ovulation control in postpartum suckled beef cows. J. Anim. Sci. 79:2253-2259.

Larson, J. E., G. C. Lamb, J. S. Stevenson, S. K. Johnson, M. K. Day, T. W. Geary, D. J. Kesler, J. M. DeJarnette, F. N. Schrick, A. DiConstanzo, and J. D. Arseneau. 2006. Synchronization of estrus in suckled beef cows for detected estrus and artificial insemination and timed artificial insemination using gonadotropin-releasing hormone, prostaglandin $\mathrm{F}_{2 \alpha}$, and progesterone. J. Anim. Sci. 84:332-342.

Lucy, M. C. 2001. Reproductive loss in high-producing dairy cattle: Where will it end? J. Dairy Sci. 84:1277-1293.

Moreira, F., R. Flores, and J. Boucher. 2004a. Use of CIDR with a timed insemination protocol in lactating dairy cows during summer in Mexico. J. Dairy Sci. 87(Suppl. 1):373. (Abstr.)

Moreira, F., R. Flores, J. Boucher, and J. Chenault. 2004b. Effects of CIDR inserts on first service pregnancy rates of lactating dairy cows submitted to a presynch program and on re-resynchronization of second service in Mexico. J. Dairy Sci. 87(Suppl. 1):256. (Abstr.)

NRC. 1989. Nutrient Requirements of Dairy Cattle. 5th rev. ed. Natl. Acad. Sci. Washington, DC.

Perry, G. A., M. F. Smith, M. C. Lucy, J. A. Green, T. E. Parks, M. D. MacNeil, A. J. Roberts, and T. W. Geary. 2005. Relationship between follicle size at insemination and pregnancy success. Proc. Natl. Acad. Sci. USA 102:5268-5273.

Pursley, J. R., M. C. Wiltbank, J. S. Stevenson, J. S. Ottobre, H. A. Garverick, and L. L. Anderson. 1997. Pregnancy rates per artificial insemination for cows and heifers inseminated at a synchronized ovulation or synchronized estrus. J. Dairy Sci. 80:295-300.

Rasmussen, F. E., M. C. Wiltbank, J. O. Christensen, and R. R. Grummer. 1996. Effects of fenprostalene and estradiol-17-betabenzoate on parturition and retained placenta in dairy cows and heifers. J. Dairy Sci. 79:227-234.

Rathbone, M. J., C. R. Bunt, C. R. Ogle, S. Burggraaf, K. L. Macmillan, C. R. Burke, and K. L. Pickering. 2002. Reengineering of a commercially available bovine intravaginal insert (CIDR insert) containing progesterone. J. Control. Release 85:105-110.

Robinson, N. A., K. E. Leslie, and J. S. Walton. 1989. Effect of treatment of progesterone on pregnancy rate and plasma concentrations of progesterone in Holstein cows. J. Dairy Sci. 72:202-210.

Rutigliano, H. M., and J. E. P. Santos. 2005. Interrelationships among parity, body condition score (BCS), milk yield, AI protocol, and cyclicity with embryonic survival in lactating dairy cows. J. Dairy Sci. 88(Suppl. 1):39. (Abstr.)

Sangsritavong, S., D. K. Combs, R. Sartori, L. E. Armentano, and M. C. Wiltbank. 2002. High feed intake increases liver blood flow and metabolism of progesterone and estradiol- $17 \beta$ in dairy cattle. J. Dairy Sci. 85:2831-2842.

Schams, D., and B. Berisha. 2002. Steroids as local regulators of ovarian activity in domestic animals. Domest. Anim. Endocrinol. 23:53-65.

Skaggs, C. L., B. V. Able, and J. S. Stevenson. 1986. Pulsatile or continuous infusion of luteinizing hormone-releasing hormone and hormonal concentrations in prepubertal beef heifers. J. Anim. Sci. 62:1034-1048.

Smith, M. W., and J. S. Stevenson. 1995. Fate of the dominant follicle, embryonal survival, and pregnancy rates in dairy cattle treated with prostaglandin $\mathrm{F}_{2 \alpha}$ and progestins in the absence or presence of a function al corpus luteum. J. Anim. Sci. 73:3743-3751.

Stevenson, J. S., G. C. Lamb, S. K. Johnson, M. A. Medina-Britos, D. M. Grieger, K. R. Harmoney, J. A. Cartmill, S. Z. El-Zarkouny, C. R. Dahlen, and T. J. Marple. 2003. Supplemental norgestomet, progesterone, or melengestrol acetate increases pregnancy rates in suckled beef cows after timed inseminations. J. Anim. Sci. 81:571-586.

Thatcher, W. W., T. R. Bilby, J. A. Bartolome, F. Silvestre, C. R. Staples, and J. E. P. Santos. 2006. Strategies for improving fertility in the modern dairy cow. Theriogenology 65:30-44.

Thompson, K. E., J. S. Stevenson, G. C. Lamb, D. M. Grieger, and C. A. Loest. 1999. Follicular, hormonal, and pregnancy responses of early postpartum suckled beef cows to $\mathrm{GnRH}$, norgestomet, and prostaglandin $\mathrm{PGF}_{2 \alpha}$. J. Anim. Sci. 77:1823-1832.

Wiltbank, M. C., P. M. Fricke, S. Sangsritavong, R. Sartori, and O. J. Ginther. 2000. Mechanisms that prevent and produce double ovulations in dairy cattle. J. Dairy Sci. 83:2998-3007.

Wolfenson, D., G. Inbar, Z. Roth, M. Kaim, A. Bloch, and R. BrawTal. 2004. Follicular dynamics and concentrations of steroids and gonadotropins in lactating cows and nulliparous heifers. Theriogenology 62:1042-1055. 